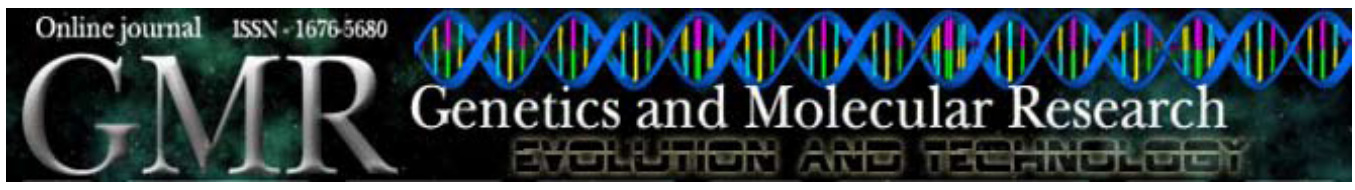

\title{
Genetic diversity of natural populations of Anemopaegma arvense (Bignoniaceae) in the Cerrado of São Paulo State, Brazil
}

\author{
A.P. Batistini' ${ }^{1}$ M.P.C. Telles ${ }^{2}$, B.W. Bertoni ${ }^{3}$, J. da S. Coppede ${ }^{4}$, \\ F.V. Môro ${ }^{1}$, S. de C. França ${ }^{3}$ and A.M.S. Pereira ${ }^{3}$ \\ ${ }^{1}$ Departamento de Biologia Aplicada à Agropecuária, \\ Faculdade de Ciências Agrárias e Veterinárias, \\ Universidade Estadual Paulista, Jaboticabal, SP, Brasil \\ ${ }^{2}$ Laboratório de Genética e Biodiversidade, \\ Universidade Católica de Goiás, Goiânia, GO, Brasil \\ ${ }^{3}$ Unidade de Biotecnologia de Plantas Medicinais, \\ Universidade de Ribeirão Preto, Ribeirão Preto, SP, Brasil \\ ${ }^{4}$ Programa de Pós-Graduação em Biotecnologia, \\ Universidade de Ribeirão Preto, Ribeirão Preto, SP, Brasil \\ Corresponding author: B.W. Bertoni \\ E-mail: bbertoni@unaerp.br
}

Genet. Mol. Res. 8 (1): 52-63 (2009)

Received October 15, 2008

Accepted November 14, 2008

Published January 20,2009

\begin{abstract}
Catuaba (Anemopaegma arvense), a Bignoniaceae species endemic to Cerrado regions, shows anticancer properties and is widely used as a stimulant in traditional medicine. We evaluated the genetic diversity of seven populations found in the State of São Paulo, using random amplified polymorphic DNA markers. After optimization of the amplification reaction, 10 selected primers produced 70 reproducible bands, with $72.8 \%$ polymorphism. The greatest genetic diversity was observed within populations $(71.72 \%)$. Variation estimates, $\theta^{\mathrm{B}}(0.2421)$ and $\Phi_{\mathrm{ST}}(0.283)$, obtained by inter- and intra-populational analysis of genetic variability of catuaba, indicated
\end{abstract}


considerable population structure. However, the $\mathrm{r}$ value $0.346(\mathrm{P}=$ 0.099), calculated by the Mantel test, indicates that the genetic diversity among populations is not strongly structured in geographical space, although there appears to be a tendency towards structuring.

Key words: Random amplified polymorphic DNA; Preservation; Bignoniaceae; Medicinal plant

\section{INTRODUCTION}

The reduction in size of areas covered by their original vegetation and the increasing isolation of their remains by habitat fragmentation constitute a significant threat to biodiversity preservation and therefore to their genetic resources (Fahrig, 2003). This is a reality for various Brazilian biomes, mainly those of the Mata Atlântica (Atlantic Forest) and the Cerrado; the more they are fragmented and the larger the landscapes become, the greater are the challenges for the preservation of their genetic resources (Costa and Scariot, 2003).

Over the last years, the Cerrado that extends over $356,630 \mathrm{~km}^{2}$ of the remaining vegetation, i.e., $20 \%$ of their original area, has been undergoing a process of fragmentation caused by the expansion of agricultural borders and consequently an increase in areas utilized for agriculture and ranching. This expansion has led to habitat fragmentation for various species, leading the Cerrado to be recently considered one of the 25 leading world "hotspots" for biodiversity preservation (Myers et al., 2000), where preservation strategies are of fundamental importance.

Among the Cerrado's endemic species is Anemopaegma arvense, a plant intensively studied by Japanese research groups, that hold several patents related to their cell rejuvenation activity in skin and anti-tumor action (Hiroyuki et al., 2000; Shimizu, 2001; Yamashita and Fujita, 2002; Mio et al., 2003; Uchino et al., 2004). A. arvense has been considered to be a vulnerable species in the list of flora components threatened by extinction in Brazil, due to extractivism by regional people and phytotherapy laboratories.

The genus Anemopaegma occurs throughout the tropical regions of the planet, including areas from Mexico to Brazil and Argentina. A. arvense (Figure 1) possesses a subarbustive habit, forming low shrubs of a dark green color; a circular section striated when present, and simple stem hairs. A longish xylopodium is always present. It has sessile leaves or a very short petiole, opposing, composed of three long, narrow leaflets, of revolute margins, uninerved. A. arvense also has the following features: terminal or axile inflorescence, white or whitish-yellow flower, 5-dented calyx, tubular corolla, infundibuliform; androecium with 4 stamens and one filiform stamodium didynamous stamens; supra-ovary gynoecium capsule type, flattened fruit, thick hard woody valvae; winged seeds, circular, light-colored membranous wings (Ferri, 1969; Ferreira, 1973). No information about the floral/reproductive biology of the $A$. arvense species is available in the literature, nor is its genetic diversity known. At present, one of the most employed methods for the characterization of genetic variability of plants threatented by extinction involves molecular marker technology, an important tool of programs aimed at biodiversity preservation, which supplies information about the genetic structure of natural populations (Avise, 2004). 


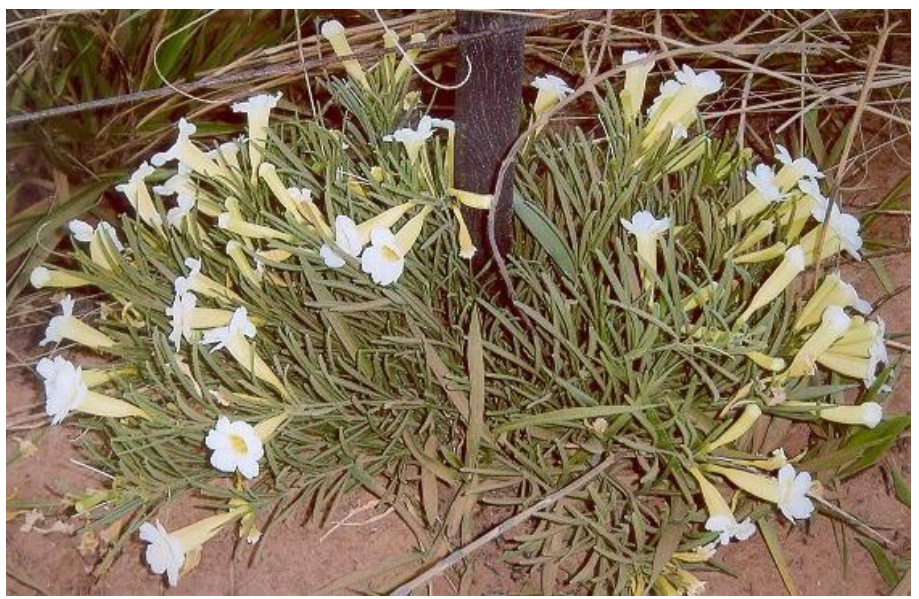

Figure 1. General appearance of flowering Anemopaegma arvense.

The objective of the present study was to analyze the variability and genetic structure of seven populations of $A$. arvense, localized in the remains of the Cerrado of São Paulo State, utilizing molecular markers of the random amplified polymorphic DNA (RAPD) type.

\section{MATERIAL AND METHODS}

The study utilized $106 \mathrm{~A}$. arvense individuals, randomly collected from sites representative of the distribution of this species in São Paulo State. Twenty-five individuals were collected at the Conservation Unit of the State Park of Furnas of Bom Jesus (Pedregulho), 15 at the Biological Reserve of Mogi-Guaçu, and the rest from the municipalities of Itatinga (9 individuals), Bauru (7), Brotas (11), Paraguaçu-Paulista (20), and Iaras (19).

The portable satellite receiver used for all collections was the GPS (Garmin Modelo Legendado-79728002). Data were processed by the Trackmaker software; information about the distances between populations is reported in Table 1 .

Exsiccates of all samples were prepared and stored at the Herbarium of Medicinal Plants of the University of Ribeirão Preto (HPM - UNAERP, São Paulo State, Brazil). Genomic DNA of young leaves was isolated according to the protocol proposed by Doyle and Doyle (1987).

\section{RAPD amplification protocol}

A. arvense DNA samples were initially evaluated with 91 primers (Operon Life Technology and Biosynthesis Incorporated), among which 38 were selected. Using the amplification protocol of Ferreira and Grattapaglia (1998), different annealing temperatures and reaction component concentrations were tested. The reaction products were separated by electrophoresis on $1.5 \%(\mathrm{w} / \mathrm{v})$ agarose gels stained with ethidium bromide. A DNA 100-bp molecular weight marker was run with each gel. All reagents utilized were from Amersham Biosciences do Brasil Ltda. Gels were photographed using a ultraviolet light transiluminator 
(Image Master ${ }^{\circledR}$ VDS, Pharmacia Biotech). Only bands reproducible by different analyses were considered, and weak amplifications were excluded. Control samples containing all reaction reagents except DNA were evaluated to verify the presence of contaminants.

\section{Statistical analyses}

The matrix of binary data was submitted to the analysis of variance (ANOVA) of allele frequencies analogous to that proposed by Weir and Cockerham (1984), that utilizes a methodology developed for data of dominant markers starting with a Bayesian approach (Holsinger et al., 2002). This methodology a priori does not presuppose the occurrence of endogamy or Hardy-Weinberg equilibrium in a local population. The Hickory version 1.0 software permits the estimation of $\theta^{\mathrm{B}}$ by means of four different models. The first one, referred to as "full model", permits the estimation of both $\theta^{\mathrm{B}}$ and $f$. The second and third models permit one to assume that $\theta^{\mathrm{B}}$ and $f$ are equal to zero, respectively. Finally, due to the fact that the estimate of $f$ based on dominant markers is usually slanted (especially when small samples, $\mathrm{n}<10$, are used), the model utilized by Hickory version 1.0 permits $f$ to remain free to vary. In this case, the model chooses $f$ values in a random fashion for a priori distribution, while estimating the other parameters with the Markov Chain Monte Carlo analysis. The results from these models are then compared using the "deviant information criterion (DIC)" (Holsinger, 1999; Spiegelhalter et al., 2002; Holsinger and Wallace, 2004). According to Spiegelhalter et al., 2002, the DIC value can then be utilized to make a decision about which of the four models suits best the group of data analyzed. Dbar parameter is a measure of how the model adjusts itself to the data (the smaller, the better). $D I C$ also takes into account the approximate number of parameters estimated $(p D)$. Models that showed the smallest $D I C$ values are preferred; however, the differences between models below 5 or 6 units are very small and should not be utilized for decision making. Although the models with lower DIC are generally preferred, the model best fitting the data (low Dbar values) may be chosen when differences between DICs are negligible.

Molecular analysis of variance (AMOVA), permits the unfolding of the distance between and within local populations, utilizing a strategy similar to that performed in conventional ANOVA, but starts from a Euclidian distance matrix calculated between individuals, based on the presence or absence of RAPD bands. Individuals can also be grouped according to non-genetic criteria, such as geographic, ecologic and environmental ones. The inter-population variance component is extracted by expectation equations of mean squares, according to conventional ANOVA of allele frequencies utilized to estimate $\mathrm{F}_{\mathrm{ST}}$ (Cockerham, 1969, 1973). The same procedure can be used on the basis of the unfolding of the sum of squares between distances, utilizing the statistics called s- $\Phi$. The calculator $\Phi_{\mathrm{ST}}$, analogous to $\mathrm{F}_{\mathrm{ST}}$, is interpreted as being the correlation of random haplotypes within populations in relation to each random pair pulled out from the total of the species. In order to obtain a null distribution of these statistics, randomizing procedures by random permutations of rows (and corresponding columns) of the matrix of the squared distances were utilized (Mantel, 1967). Variance components were estimated for each permuted matrix (approximately 1000 permutations), performed by AMOVA-PREP 1.01 and WINAMOVA 1.04 programs.

Following the estimation of the genetic divergence, the matrix of the genetic distances $\left(\theta^{\mathrm{B}}\right.$ pair to pair) was analyzed by means of grouping using UPGMA (unweighted pair-group method by arithmetic averages), which produces a hierarchic arrangement of the population classification 
represented by a dendrogram. The representativity of this dendrogram was tested by the correlation between the original distances and the distances between populations of the dendrogram (cophenetic correlation), showing the relation between these populations (Lessa, 1990).

In order to analyze the patterns of spatial variation of the genetic variability in a multivariate context, an estimate of Pearson's correlation coefficient (r) between matrices of genetic and geographic distances between the populations (Epperson, 2003) was made. The significance of this matricial correlation could not be tested by usual statistics because it shows independence problems between matrix elements. Therefore, the Z statistic of Mantel (1967) has been often utilized to test the significance of the association between matrices containing different types of distances between paired observations (Smouse et al., 1986; Manly, 1997). The significance of $Z$ can be obtained by comparing this observed value with values of a null distribution, built by recalculating the values of $Z$ several times, rendering the order of the elements of one of the matrices random in each one. The $\mathrm{Z}$ statistic possesses a monotonic relation with Pearson's r, calculated between matrices (matricial correlation), so that it can be utilized to test r's significance (Manly, 1986). In the present study, 5000 random permutations were utilized to test the significance of matricial correlations.

\section{RESULTS}

\section{RAPD amplification protocol}

Among the 38 primers selected, 10 were chosen (Table 1) that showed high polymorphism and best band intensity. Following optimization of the polymerase chain reaction parameters for genetic material under study, the following protocol for $A$. arvense was set up (final amplification reaction volume $=30 \mu \mathrm{L}$ ): $3.0 \mu \mathrm{L}$ buffer $10 \mathrm{X} ; 3.0 \mu \mathrm{L}$ dNTPs $(2.5 \mathrm{mM}$ ); $1.8 \mu \mathrm{L} \mathrm{MgCl}_{2}(25.0 \mathrm{mM}) ; 4.0 \mu \mathrm{L}$ primer $(10 \mathrm{ng} / \mu \mathrm{L}) ; 0.3 \mu \mathrm{L}$ Taq enzyme DNA polymerase $(5$ $\mathrm{U} / \mu \mathrm{L})$, and $4.0 \mu \mathrm{L}$ of sample DNA $(5 \mathrm{ng} / \mu \mathrm{L})$. Amplification was conducted in a thermocycler as follows: 1 cycle at $94^{\circ} \mathrm{C}$ for $2 \mathrm{~min}, 2$ cycles at $37^{\circ} \mathrm{C}$ for $1 \mathrm{~min}, 72^{\circ} \mathrm{C}$ for $2 \mathrm{~min}, 33$ cycles at $94^{\circ} \mathrm{C}$ for $10 \mathrm{~s}, 40^{\circ} \mathrm{C}$ for $20 \mathrm{~s}$ (annealing temperature ) and $72^{\circ} \mathrm{C}$ for $2 \mathrm{~min}$.

\begin{tabular}{|c|c|c|c|c|}
\hline \multirow[t]{2}{*}{ Primers } & \multirow[t]{2}{*}{ Sequences $\left(5^{\prime} \rightarrow 3^{\prime}\right)$} & \multicolumn{3}{|c|}{ Number of bands } \\
\hline & & Total & Polymorphic & Monomorphic \\
\hline 1 & CAGGCCCTTC & 8 & 6 & 2 \\
\hline 2 & AGGGGTCTTG & 8 & 3 & 5 \\
\hline 3 & TGCCGAGCTG & 7 & 7 & 0 \\
\hline 4 & AGCGTCACTC & 6 & 6 & 0 \\
\hline 5 & CAGCACCCAC & 8 & 3 & 5 \\
\hline 6 & TCGCCTAGTG & 8 & 7 & 1 \\
\hline 7 & GGCAGCAGGT & 8 & 3 & 5 \\
\hline 8 & GCAACCTCCTATCTGAATC & 7 & 7 & 0 \\
\hline 9 & CACTGACATTGATACTGAAGC & 5 & 4 & 1 \\
\hline 10 & ACATGTTCAATACTAAAGCG & 5 & 5 & 0 \\
\hline Total & & 70 & 51 & 19 \\
\hline
\end{tabular}


The ten chosen primers produced 70 bands, the majority $(72.8 \%)$ polymorphic in the seven populations. The minimal number of bands per primer was 5 , and the maximal 8 (Table 1). A typical example of polymorphism detected with primer 1 is presented in Figure 2 .

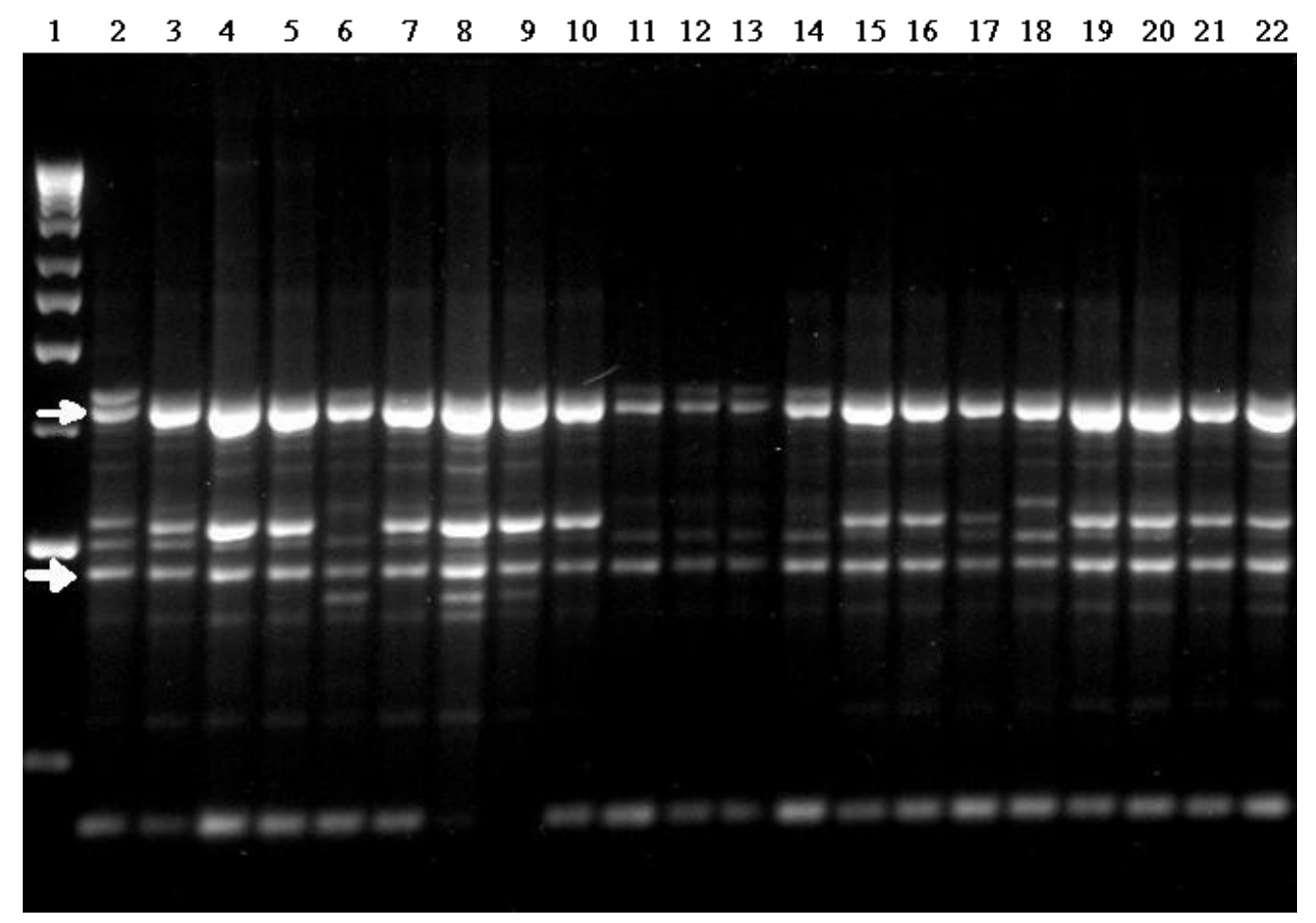

Figure 2. Random amplified polymorphic DNA band profile in natural populations of Anemopaegma arvense (lanes 2 to 22, corresponding to 9 individuals from Itatinga, 7 from Bauru and 5 from Brotas), produced by primer 1. White arrows represent monomorphic bands. 100-bp molecular weight marker in lane 1.

\section{Genetic variability between and within populations, structure and genetic distance}

The genetic characterization of the 106 individuals analyzed in the seven populations of the 70 loci studied showed an average number of 1.72 alleles (Table 2), and a total percentage of polymorphic loci of $72.8 \%$. The population of Itatinga had the highest percentage of polymorphic loci (58.6\%), followed by the population of Brotas (55.7\%) and Mogi-Guaçu (51.4\%). Nei's genetic diversity, utilizing a Bayesian approach, showed a mean value of 0.284, varying between 0.258 (Paraguaçu Paulista) and 0.335 (Itatinga). The statistical analysis of the estimation of the variation of describer parameters (Table 3), for the four models, showed that the lowest values of DIC and Dbar was for the "full model" (DIC $=1165.8795$ and Dbar = 
955.1058), in which $\theta^{\mathrm{B}}$ equaled 0.2421 , suggesting a strong structuration of genetic variability in these 70 RAPD loci. AMOVA showed that $71.2 \%$ of the genetic variability is in the intrapopulation component (Table 4). The value of $\Phi_{\mathrm{ST}}$ was significant, $0.283(\mathrm{P}<0.001)$.

Table 2. Basic descriptive statistics of Anemopaegma arvense populations of São Paulo State.

\begin{tabular}{lccccc}
\hline Population & $\mathrm{N}$ & $\mathrm{Na}$ & $\mathrm{P}$ & $\mathrm{Hs}$ & $\mathrm{H}$ \\
\hline ITA & 9 & 1.5857 & 58.6 & 0.335 & 0.344 \\
BAU & 7 & 1.4143 & 41.4 & 0.270 & 0.227 \\
BRO & 11 & 1.5571 & 55.7 & 0.301 & 0.258 \\
PP & 20 & 1.4857 & 48.6 & 0.288 & 0.262 \\
MG & 15 & 1.5143 & 51.4 & 0.266 & 0.300 \\
IA & 19 & 1.4429 & 44.3 & 0.270 & 0.250 \\
PED & 25 & 1.4143 & 41.4 & 0.284 & 0.239 \\
General & 106 & 1.7286 & 72.9 & 0.277 \\
\hline
\end{tabular}

Mean size of sampling $(\mathrm{N})$ number of alleles observed $(\mathrm{Na})$, percentage of polymorphic loci $(\mathrm{P})$, Nei's diversity by the Bayesian method (Hs). ITA = Itatinga; BAU = Bauru; BRO = Brotas; PP = Paraguaçu-Paulista; $\mathrm{MG}=$ MogiGuaçu; IA = Iaras; PED = Pedregulho.

Table 3. Results of a Bayesian analysis of the divergence among the 7 populations of Anemopaegma arvense, including models tested, estimates of $f, \theta^{\mathrm{B}}$, adjustment of model (Dbar) and "deviant information criterion" (DIC).

\begin{tabular}{lccrc}
\hline Model & $f$ & $\theta^{\mathrm{B}}$ & Dbar & DIC \\
\hline Full & 0.2046 & 0.2421 & 955.1058 & 1165.8795 \\
$f=0$ & 0.0000 & 0.2148 & 951.4989 & 1177.1718 \\
$\theta^{\mathrm{B}}=0$ & 0.4198 & 0.0000 & 2122.1383 & 2175.2794 \\
free $f$ & 0.5121 & 0.2675 & 971.2389 & 1184.9623 \\
\hline
\end{tabular}

Table 4. Results of analysis of molecular variance for the 7 populations of Anemopaegma arvense based on 70 random amplified polymorphic DNA loci.

\begin{tabular}{lrrrcc}
\hline Source of variation & d.f. & SS & \% VT & P & $\Phi_{\text {ST }}$ \\
\hline Between populations & 6 & 238.06 & 28.28 & $<0.001$ & - \\
Within populations & 99 & 576.70 & 71.72 & \\
Total & 105 & 814.76 & & - \\
\hline
\end{tabular}

d.f. $=$ degrees of freedom; $\mathrm{SS}=$ sum of squares; $\% \mathrm{VT}=$ percent total variation.

The genetic distances between pairs of populations shown in this study varied between the lowest value of 0.102 (between Itatinga-Bauru and Bauru-Brotas populations) to the highest one, 0.286 (between Brotas and Pedregulho). Figure 3 shows the dendrogram based on these genetic distances made by the UPGMA method. Itatinga and Bauru distances showed $100 \%$ genetic similarity, and these populations together with those of Brotas, Paraguaçu-Paulista and Mogi-Guaçu form a group genetically distinct from the group of Iaras and Pedregulho. It is important to point out that the last two populations, in spite of being $346 \mathrm{~km}$ apart, show genetic similarity. 


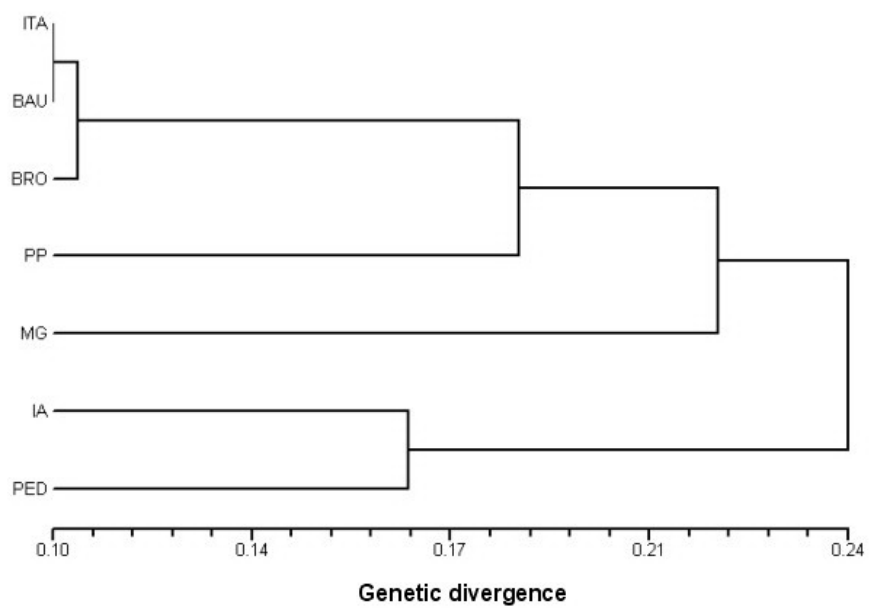

Figure 3. Pattern of genetic divergence among the 7 Anemopaegma arvense population samples in São Paulo, defined by the UPGMA grouping based on genetic distances $\theta^{\mathrm{B}}$ pair to pair (cophenetic correlation of 0.89 ). ITA = Itatinga; $\mathrm{BAU}=$ Bauru; $\mathrm{BRO}=$ Brotas; $\mathrm{PP}=$ Paraguaçu-Paulista; $\mathrm{MG}=$ Mogi-Guaçu; IA = Iaras; PED = Pedregulho.

Mantel's test to verify whether the genetic variability found in populations from catuaba is space-structured, displayed an $\mathrm{r}$ value of $0.346(\mathrm{P}=0.099)$. Therefore, there is a low but significant correlation of $10 \%$, suggesting a tendency towards a positive relation between genetic and geographic distances in these populations (Figure 4).

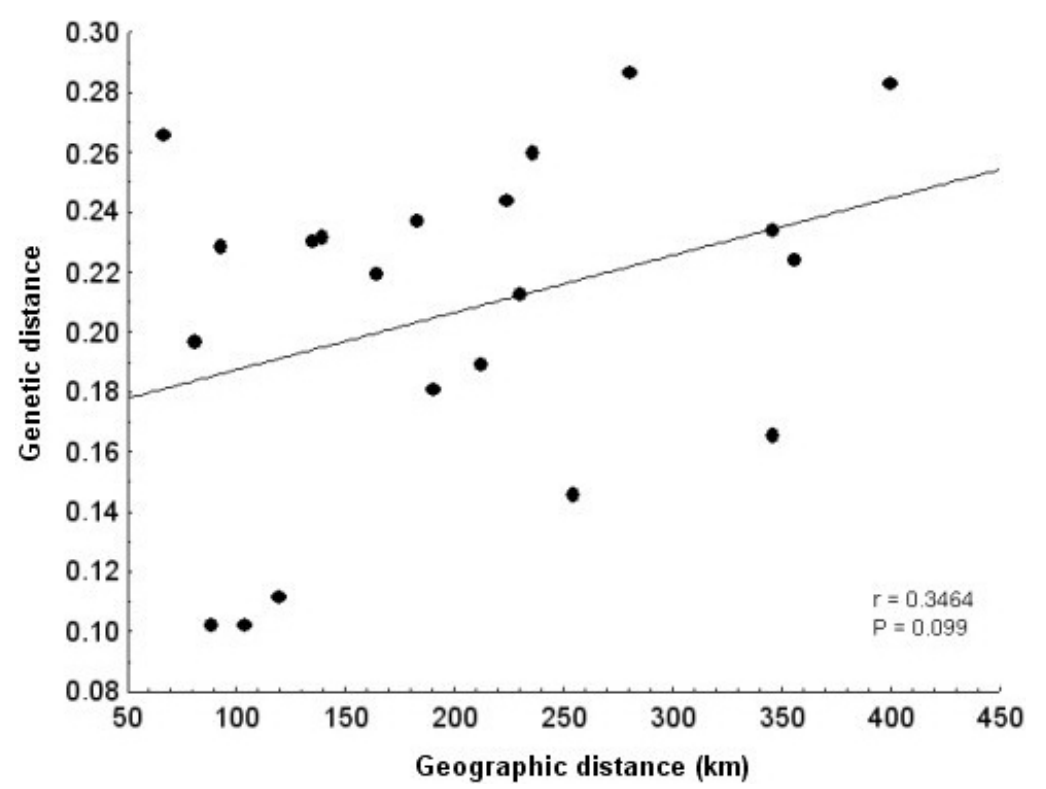

Figure 4. Relation between genetic $\left(\theta^{\mathrm{B}}\right)$ and geographic distances $(\mathrm{r}=0.3464-\mathrm{P}=0.099$, with 5000 permutations) among 7 populations of Anemopaegma arvense. 


\section{DISCUSSION}

The results presented demonstrate for the first time the genetic variability of natural populations of $A$. arvense of São Paulo State analyzed by RAPD molecular markers.

The great variability found in different statistical estimates indicates that there still exists a considerable level of genetic diversity in the seven natural populations of catuaba. There are many examples of other successful studies with RAPD markers in the research on the variability and genetic structure of natural plant populations described in the literature, e.g., by Russell et al. (1993) with cocoa, Gillies et al. (1999) with mahogany, Gauer and Cavalli-Molina (2000) with Ilex paraguariensis, Arnholdt-Schmitt (2000) with Hypericum perforatum, Sales et al. (2001) with Digitalis minor, Ciampi et al. (2003) with Tabebuia impetiginosa, and Wadt and Kageyama (2004) with Piper hispidinervum, where the last four are related to medicinal plants.

The measurement of allele frequency variation between different populations is the probability that two randomly chosen genes of two populations will be identical by descent (Futuyma, 1992). A population division can affect allele frequencies and, consequently, the proportion of genetic variability found among populations. As it can be determined by genetic variability analyses between and within catuaba populations, the variation estimates $\theta^{\mathrm{B}}$ $(0.2421)$ and $\Phi_{\mathrm{ST}}(0.283)$ were close to the limiting value of 0.25 proposed by Wright (Solferini and Selivon, 2001), indicating high population structuration.

The greater part of the genetic variability of the catuaba populations (Table 4) was identified within populations (71.72\%); a similar structuration was found in another species of Bignoniaceae (Tabebuia impetiginosa), a native medicinal arboreal, located in anthropic fragments, whose genetic variability within populations was also higher than between them on the order of $93.51 \%$ (Ciampi et al., 2003).

Seed dispersion of these two species of Bignoniaceae is by wind: they are light and possess membrane winged that favor their displacement over long distances. According to Loveless and Hamrick, 1984, seed dispersion by wind increases intra-population variation, depending on velocity and seed characteristics, where a small seed's migration over long distances is able to prevent population divergence.

$A$. arvense has an ecological interaction with fire, called pyrophitic adaptation (Coutinho, 1977). Besides promoting the opening of catuaba fruits close to the ground due to their weight, fires eliminate the whole barrier constituted by the mass of leaves and small twigs of the plant itself, as well as of the grasses and other small-sized plants growing around it. In the absence of burnings, seeds are prevented from being taken by wind over large distances thus contributing to increased genetic structuration of the population by decreasing gene flow between them. This explains the marked percentage (28.28\%) of variability among $A$. arvense populations (Table 4).

The dendrogram presented in Figure 3 shows that in spite of the Iaras population being geographically closer to Bauru $(66 \mathrm{~km})$, Brotas $(139 \mathrm{~km})$ and Itatinga $(81 \mathrm{~km})$ it is genetically closer to that of Pedregulho $(346 \mathrm{~km})$. Regarding the populations of Itatinga, Bauru and Brotas, a geographic and genetic proximity between them can be observed. Such information allows the inference that the positive, significant correlation observed between genetic distance matrices and geographic distance $(r=0.346 ; \mathrm{P}=0.099)$ corroborates the notion of the gene flow model of isolation by distance. It may therefore be concluded that the genetic divergence existing between the populations sampled is not strongly structured in geographic 
space, but that there exists a tendency for structuration, requiring new analyses on a larger scale (more populations) to ascertain whether it is maintained.

São Paulo State is the largest farming and industrial center of Brazil, and has been ever since the sixteenth century. It underwent several important economic cycles, from gold mining to coffee and sugarcane planting, all generating wealth, especially sugar cane for ethanol production, and soybean and forage crops introduced in the western-central region of the state, where the Cerrado predominates. Due to these activities, large areas of native vegetation have been progressively lost. It is presumed that the populations related to $A$. arvense in São Paulo State originate from biological processing (selection, dispersion, migration, and genetic derivation) that occurred in ancestral metapopulations. This explains why the population of Pedregulho is in the same population knot as that of Iaras in the dendrogram (Figure 3).

According to Solé-Cava, 2001, the populations of species threatened by extinction are frequently found to be structured, since in general, environmental degradation leads to the formation of shelters (fragments), where small populations of these species persist, without being able to exchange genes with other accesses situated in non-altered areas. In this study of catuaba, populations constitute the shelters, each having structuration to a high degree.

The present study on the genetic diversity of natural populations of A. arvense (Vell.) Stellf, localized in the Cerrado of São Paulo State, associated with data on micropropagation and conservation ex situ in a germplasm bank in vitro, constitute a preservation strategy adequate for Cerrado's endemic species (Pereira et al., 2003).

The best alternative for the preservation of genetic variability of $A$. arvense would be the in situ one, keeping it in its own area of natural occurrence, local adaptations favoring the establishment of the species in this natural habitat; nevertheless, with the exception of the population collected in the Mogi-Guaçu Biological Reserve, shown to be protected, all others should be conserved in a germplasm bank in order to save from extinction, especially considering that they are found in private areas with different degrees of anthropomorphization, unprotected by conservationist policies.

\section{ACKNOWLEDGMENTS}

Research supported by UNAERP, by Fundação de Amparo à Pesquisa do Estado de São Paulo (FAPESP) and by the Programa de Demanda Social da Coordenação de Aperfeiçoamento de Pessoal de Nível Superior (CAPES), as an integral part of the Program for Research on Sustained Conservation of Biodiversity of the State of São Paulo Biota-FAPESP under project number 99-10610/1.

\section{REFERENCES}

Arnholdt-Schmitt B (2000). RAPD analysis: a method to investigate aspects of the reproductive biology of Hypericum perforatum L. Theor. Appl. Genet. 100: 906-911.

Avise JC (2004). Molecular Markers, Natural History, and Evolution. Sinauer Associates Inc., Sunderland.

Ciampi AY, Azevedo VCR and da Silva VP (2003). Análise genética populacional de Tabebuia impetiginosa utilizando marcadores moleculares RAPD. Bol. Pesq. Des. EMBRAPA Rec. Genet. Biotecnol. 55: 1-18.

Cockerham CC (1969). Variance of gene frequencies. Evolution 23: 72-84.

Cockerham CC (1973). Analyses of gene frequencies. Genetics 74: 679-700.

Costa RB and Scariot A (2003). A Fragmentação Florestal e os Recursos Genéticos. In: Fragmentação Florestal e Alternativa de Desenvolvimento Rural na Região Centro-Oeste (Costa RB, ed.). Universidade Católica Dom Bosco 
(UCDB), Campo Grande, 53-75.

Coutinho LM (1977). Aspectos ecológicos do fogo no Cerrado. II - As queimadas e a dispersão de sementes em algumas espécies anemocóricas do estrato herbáceo-subarbustivo. Bol. Bot. 5: 57-64.

Doyle JJ and Doyle JL (1987). Isolation of plant DNA from fresh tissue. Focus 12: 13-15.

Epperson BK (2003). Geographical Genetics. Princeton University Press, New Jersey.

Fahrig L (2003). Effects of habitat fragmentation on biodiversity. Ann. Rev. Ecol. Syst. 34: 487-515.

Ferreira MB (1973). Bignoniaceae do Distrito Federal - I. O gênero Anemopaegma Mart. Oréades. Departamento de Botânica do Instituto de Ciências Biológicas, UFMG, Belo Horizonte.

Ferreira ME and Grattapaglia D (1998). Introdução ao Uso de Marcadores Moleculares em Análise Genética. EMBRAPA - CENARGEN, Brasília.

Ferri MG (1969). Plantas do Brasil: Espécies do Cerrado. Edgard Blucher Ltda., São Paulo.

Futuyma DJ (1992). Biologia Evolutiva. Sociedade Brasileira de Genética/CNPq, Ribeirão Preto.

Gauer L and Cavalli-Molina S (2000). Genetic variation in natural populations of mate (Ilex paraguariensis A. St.-Hil., Aquifoliaceae) using RAPD markers. Heredity 84 (Pt 6): 647-656.

Gillies ACM, Navarro C, Lowe AJ, Newton AC, et al. (1999). Genetic diversity in Mesoamerican populations of mahogany (Swietenia macrophylla), assessed using RAPDs. Heredity 83: 722-732.

Hiroyuki H, Akio M and Tomonori K (2000). Skin external use agent. Available at [www.j-Tokkyo.com/2000/A61K/ JP2000-143482.shtml].

Holsinger KE (1999). Analysis of genetic diversity in geographically structured populations: a Bayesian perspective. Hereditas 130: 245-255.

Holsinger KE and Wallace LE (2004). Bayesian approaches for the analysis of population genetic structure: an example from Platanthera leucophaea (Orchidaceae). Mol. Ecol. 13: 887-894.

Holsinger KE, Lewis PO and Dey DK (2002). A Bayesian approach to inferring population structure from dominant markers. Mol. Ecol. 11: 1157-1164.

Lessa EP (1990). Multidimensional analysis of geographic genetic structure. Syst. Zool. 39: 242-252.

Loveless MD and Hamrick JL (1984). Ecological determinants of genetic structure in plant populations. Ann. Rev. Ecol. Syst. 15: 65-95.

Manly BFJ (1986). Multivariate Statistical Methods: A Primer. Chapman and Hall, London, New York.

Manly BFJ (1997). Randomization, Bootstrap and Monte Carlo Methods in Biology. Chapman and Hall, London.

Mantel N (1967). The detection of disease clustering and a generalized regression approach. Cancer Res. 27: 209-220.

Mio K, Inoure A, Yokoyama D, Atsushi N, et al. (2003). Oral Hair Growth Stimulants Containing Odd-numbered Fatty Acids, or Alcohols, Plant or Algae Extracts, and/or Tocotrienol and Foods Containing them. CODEN:JKXXAF JP 2003160486 A2 20030603. Patent written in Japanese. Application: JP 2002-26986 20020913. Priority: JP 2001-281351 20010917. CAN 138:400871 AN 2003:424466 CAPLUS (Copyright 2003 ACS on SciFinder (R)).

Myers N, Mittermeier RA, Mittermeier CG, da Fonseca GA, et al. (2000). Biodiversity hotspots for conservation priorities. Nature 403: 853-858.

Pereira AM, Amui SF, Bertoni BW, Moraes RM, et al. (2003). Micropropagation of Anemopaegma arvense: conservation of an endangered medicinal plant. Planta Med. 69: 571-573.

Russell JR, Hosein F, Johnson E, Waugh R, et al. (1993). Genetic differentiation of cocoa (Theobroma cacao L.) populations revealed by RAPD analysis. Mol. Ecol. 2: 89-97.

Sales E, Nebauer SG, Mus M and Segura J (2001). Population genetic study in the Balearic endemic plant species Digitalis minor (Scrophulariaceae) using RAPD markers. Am. J. Bot. 88: 1750-1759.

Shimizu H (2001). Antioxidant Containing Plant Extracts for Cosmetics and Pharmaceuticals. JP - patent number, 20011139417.

Smouse PE, Long JC and Sokal RR (1986). Multiple regression and correlation extensions of the Mantel test of matrix correspondence. Syst. Zool. 35: 627-632.

Solé-Cava AM (2001). Biodiversidade Molecular e Genética da Conservação. In: Biologia Molecular e Evolução (Matioli SR, ed.). Editora Holos, Ribeirão Preto, 172-192.

Solferini VN and Selivon D (2001). Polimorfismos de Isozimas. In: Biologia Molecular e Evolução (Matioli SR, ed.). Editora Holos, Ribeirão Preto, 139-142.

Spiegelhalter DJ, Best NG, Carlin BP and Van der Linde A (2002). Bayesian measures of model complexity and fit. J. R. Stat. Soc. 64: 583-639.

Uchino T, Kawahara N, Sekita S, Satake M, et al. (2004). Potent protecting effects of Catuaba (Anemopaegma mirandum) extracts against hydroperoxide-induced cytotoxicity. Toxicol. In Vitro 18: 255-263.

Wadt LHO and Kageyama PY (2004). Estrutura genética e sistema de acasalamento de Piper hispidinervum. Pesq. 
Agropec. Bras. 39: 151-157.

Weir BS and Cockerham CC (1984). Estimating F-statistics for the analysis of population structure. Evolution 38: 1358-1370.

Yamashita M and Fujita S (2002). Cosmetics Containing sunscreen Agents and Plant Extracts. PR. Available at [www.j-Tokkyo. com/2002/A61K/JP2002-308750.shtml]. 